\title{
Natural Resources Endowment and African' Countries Private Enterprises Productivity
}

\author{
B. Denis Akouwerabou \\ University Ouaga II, \\ Economics Department, Burkina Faso \\ Abdi Yuya Ahmad \\ Adama Science and Technology University, \\ Ethiopia \\ G. G. Legala Keudem \\ University Ouaga II, \\ Economics Department, Burkina Faso
}

\begin{abstract}
Abundant literature has focused on the phenomenon called "the curse of natural resources". So far, all authors who have studied the resource curse have focused on the relationship between the endowment of natural resources and macroeconomic growth. We empirically test the existence of this phenomenon using the data of 6581 private enterprises from twenty-four African countries that are rich and poor in natural resources. The data show that enterprises that are set up in countries extracting huge quantities of energizing natural resources are inefficient compared to those in countries poor in natural resources. The extent of the harmful effect of the richness in natural resources on enterprises' productivity is still more important in countries where share of natural resources in exportation income is very high.
\end{abstract}

Keywords: Curse of Natural Resources, Private Enterprise, African Countries, Efficiency.

\section{INTRODUCTION}

Theoretically, natural resources represent gifts that increase countries' physical capital and accelerate their economic growth. However, the stylized facts show that countries rich in natural resources have recorded economic growth rates lower than countries that are not (Farhadi, Islam and Moslehi, 2013). This phenomenon, called the resource curse, was highlighted by Sachs and Warner (1995). The resource curse has been demonstrated by several empirical studies, and it seems to be adopted as a standard result (Sachs and Warner, 2001, 1997 and; Auty and Mikesell, 1998).

The causes of the resource curse are many. Structuralist theory attributes the origin of the resource curse to the decline in the terms of exchange between primary products and manufactured products (Prebisch, 1950 quoted by Torres Alfonso and Soares, 2013). Hirschman (1958) thinks that the resource curse results from the volatility of the primary products' price and the weak connection between the natural resources sector and the rest of the economy. None of these hypotheses has been confirmed by the empirical tests. Van der Ploeg (2011); Qureshi (2008) and Hartford and Klein (2005) recently introduced a new hypothesis by showing how this phenomenon draws its origins from the poor quality of institutions. 
The relationship between the abundance of natural resources and the quality of institutions seems reciprocal. Mahlum et al. (2006a) show that an abundance of resources can also affect institutions. For example, Kaufmann, Kraay and Mastruzzi (2007) show that the index of bad governance is higher in countries rich in natural resources. Likewise, Papyrakis and Gerlagh (2007) find in, in a case study of the US, that the abundance of natural resources increases practices of corruption. However, Isham et al. (2005) and Sala-i-Martin and Subramanian (2003) show that when institutions' quality reaches a certain threshold, the abundance of natural resources does not negatively affect economic growth.

Other hypotheses have also been given to justify the resource curse. Sachs and Warner (2001) think that the resource curse is due to the decrease of motivation in entrepreneurship. Gylfason, (2001a); Papyrakis and Gerlagh, (2007) believe that the phenomenon comes from the decrease in savings and in the investment in physical capital. Other researchers, such as Gylfason (2001b); Birdsall, Pinckney and Sabot (2001) and Bravo-Ortega and Gregorio (2007), think that the origin of this phenomenon is the reduction of expenditure and investment in education and health care. Atkinson and Hamilton (2003) show that the curse of natural resources results in the government's incompetency to manage well the income from the natural resources sector.

African countries have a great endowment of natural resources (African Development Bank, 2007). Normally, the abundance of natural resources should be an economic growth catalyst for those countries. For example, it should be possible to switch from economies of exporting primary products to economies of intensive manufactured production in labour. Several African countries are not yet industrialized and have stopped moving in the hatch of semidevelopment, where they depend on the export of a few natural resources such as oil, gas and ore.

Given that in the market economy, private enterprises are the main economic growth catalysts, we suppose that this result (resource curse) will remain when we consider the private enterprises of these two categories of countries. Specifically, we aim to test the hypothesis that the private enterprises of countries wealthy in natural resources are less efficient to those of countries with fewer natural resources. Our main contribution therefore consists of testing the existence of the resource curse not on macroeconomic data but on private enterprises' data.

The data used are private enterprises' data collected in twenty-four African countries by the World Bank. This survey has covered several aspects of private enterprises. The database contains information on the overall number of employees, physical capital, illicit payments and annual income. Former approaches have all been macroeconomic analyses and thus have used models of growth by Mauro (1995), Mankiw et al. (1992) or Barro (1991). Given that our study uses enterprises' data, we use a slightly different method. First, we use the method of Data Envelopment Analysis (DEA) to estimate the technical efficiency scores of the enterprises of each country. Then, through a Tobit model, we identify the determinants of these efficiency scores.

The rest of the article is organized as follows: Section 2 shows the existence of the resource curse in Africa via a literature review before showing how this phenomenon is passed on in private enterprises. Section 3 theoretically shows how enterprises' technical efficiency scores have been diverted. In this section, we also show the Tobit model of the determinants of those efficiency scores. Sections 4 and 5, respectively, present the data used and the econometric results analysis. 


\section{RESOURCES CURSE AND PRIVATE ENTERPRISES' PRODUCTIVITY}

The ways that the resource curse is passed on to private enterprises are known. Investing in human capital influences economic growth. Barro (1991), Mankiw et al. (1992) and Barro and Sala-i-Martin (1995) emphasized the importance of human capital in the economic development process. However, it has been shown that when the quasi-totality of a country's labour is in the primary sector, this reduces the investment in education (Gylfaon, Herbertsson and Zoega, 1999). Thus, if the abundance of natural resources tends to inhibit economic growth, it is because resource-wealthy countries under invest in human capital. The low accumulation of human capital on the national scale is seen on the enterprises' scale based on low productivity growth. To circumvent the lack of qualified labour, enterprises can relocate and import natural resources. The waves of relocation will lead to a deindustrialization in natural resource-wealthy countries (Matsuyama, 1992).

The abundance of natural resources should represent a growth opportunity for private enterprises. Put simply, being settled in a country where the cost of access to raw materials (natural resources) is almost null is a great advantage for an enterprise. According to Krugman (1987), this asset is still more profitable to an enterprise if a country has access to the sea. However, the abundance of natural resources in a country is not enough to increase privatesector dynamism in terms of the number of enterprises being set up (Torvik, 2009). Sachs and Warner (1995) show that the abundance of natural resources leads to foreign direct investments (FDI) only when the transportation of the raw natural resource is too costly. With the increase in manufactured products, the size of the FDI in the search for natural resources has increased (DeLong and Williamson, 1994). More than 40 billion US dollars has been invested in the extractive industries since 2005 in countries such Mozambique, the Democratic Republic of Congo, Mongolia and Myanmar (Stevens, Lahm and Kooroshy, 2015). However, the development of extractive industries has not helped boost the economic growth in African countries wealthy in natural resources.

\section{THEORETICAL MODEL OF THE DETERMINANTS OF ENTERPRISES' TECHNICAL EFFICIENCY}

In the current research, we focus on the analysis of the technical efficiency of a group of enterprises in African countries. The data at our disposal do not contain information concerning the prices; therefore, we are hindered from talking about allocative efficiency. The difference between the quantities of output carried out by an enterprise and the maximum quantity that it should be able to produce regarding the quantities of inputs used can be utilized as a technical inefficiency measure (Charnes, Cooper, Levin and Seiford, 1994). To be able to capture the technical efficiency scores, researchers usually use parametric stochastic production function. The disadvantage to the stochastic production frontier method is that it can have a dysfunctional specification. The data envelopment analysis (DEA) method has been introduced as an alternative method. The DEA method is likely to be non-parametric and consequently does not require a functional form. Furthermore, the DEA's method is robust visà-vis the problems of multicollinearity and heteroscedasticity (Akazili, Adjuik, Jehu-Appiah and Zere, 2008).

In our analysis, we use the DEA ${ }^{1}$ method to evaluate the efficiency scores of the enterprises in the sample. In this respect, we maximize the enterprises' efficiency scores, hypothesizing that

\footnotetext{
1 The Figure B1 and B2 presented in the annex actually show that the DEA method is more adapted to our data comparatively to the parametric method. The efficiency scores obtained through the DEA method are set between 0 and 100. But those obtained using the stochastic frontier have been concentrated between 95 and 100 . The
} 
none has an efficiency score higher than $100 \%$. Likewise, we suppose that the efficiency scores cannot take a negative value. Letting be the scores of enterprises' efficiency, the linear program $^{2}$ we are going to solve is as follows:

$$
\begin{array}{llll} 
& & & \\
& y_{i}+Y & & \\
\text { SC: } & x_{k i} & X & 0 \\
& & & 0
\end{array}
$$

In this linear program, is a scalar and is a vector $(N \cdot 1)$ of constants. The value of represents the value of the technical efficiency; consequently, we have $0 \quad 1 . N$ represents the sample size. $X$ and $Y$, respectively, represent the input and output vectors of $N$ enterprises. $y_{i}$ and $x_{k i}$, respectively, represent the output of firm $i$ and the $k^{\text {th }}$ input of the same enterprise.

From this model, we manage to derive the levels of the enterprises' efficiency scores. Next, we have to search for the determinants of those levels of efficiency. Because the efficiency scores are between zero and one [ $\left.\begin{array}{ll}0 & 1\end{array}\right]$, we must use a model that ensures us that the predicted values will remain in this interval. In this respect, we will use a Tobit model of a dependent variable truncated in the two sides.

If ${ }^{*}$ is the latent variable or the true value of the efficiency of each firm, we can present our Tobit model as follows:

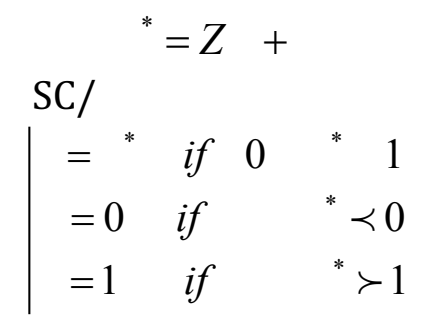

where $Z$ represents the vector of the exogenous variables that are likely to influence the enterprise's technical efficiency, is the vector of parameters to estimate, and is the error term.

\section{DATA COLLECTION}

The data used in this study were collected from the private firms of twenty-four African countries by the World Bank. The World Bank's survey focused on 24 African countries' private companies.

efficiency scores seem then to be overestimated through the parametric method. Parametric method is also good when we use physical data of inputs and outputs.

${ }^{2}$ For the need of simplification, we have decided to present the dual function of the program of maximization of the efficiency score. 
Table 1: Definition of variables used in the econometric models Variables Descriptions

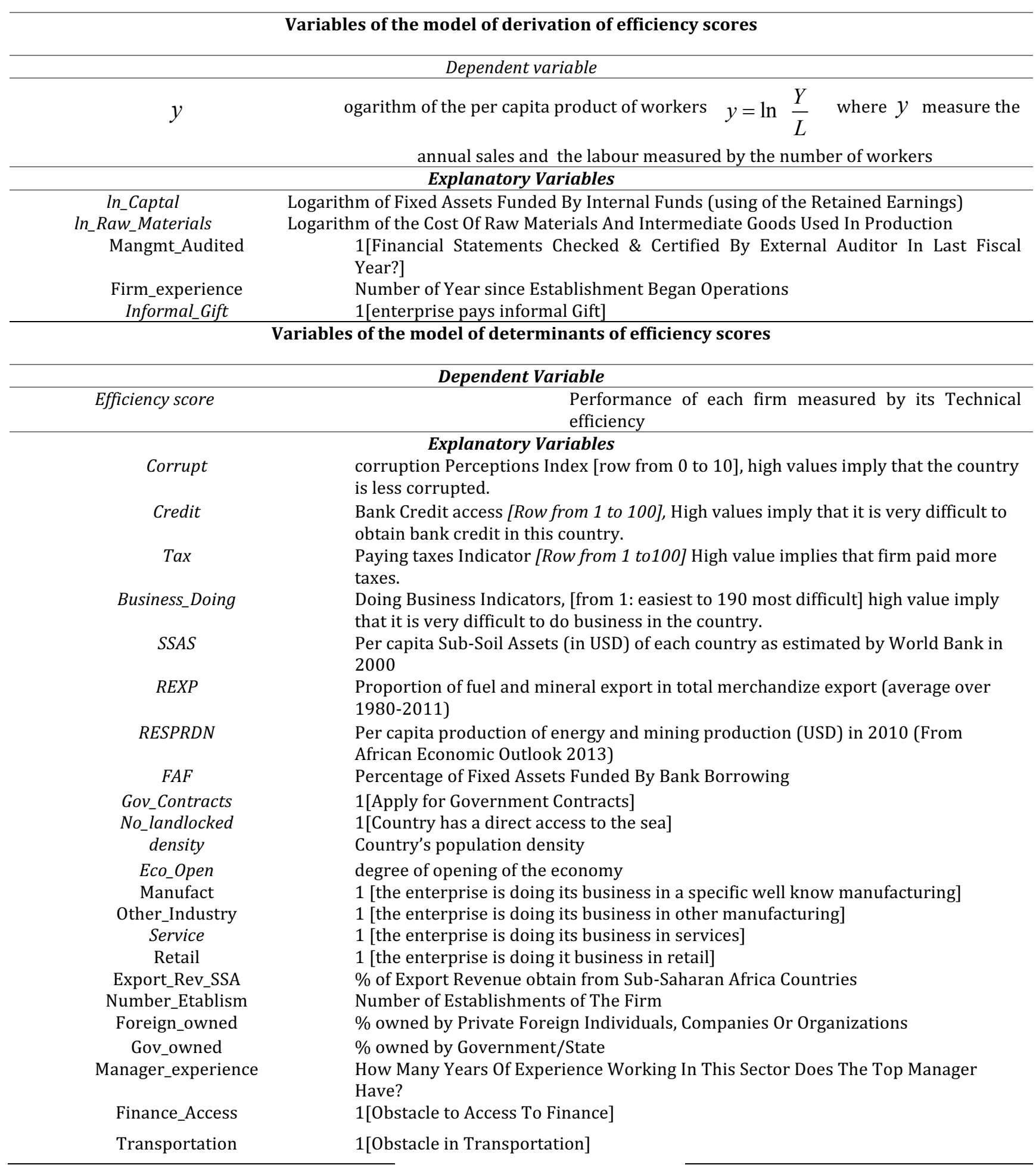

\section{Source: Built by the authors}

\section{DESCRIPTIVE STATISTICS ANALYSIS}

The data in the first row of table 2 show that the enterprises of the sample have an average technical efficiency of 7.58\%. Because the efficiency score's row is between 0 and 100 per cent, we can say that the average efficiency score is very low. The weakness of the efficiency of these countries' enterprises can be explained by many factors. 
First, the corruption index has a maximum value of approximately 5.8 in these countries. In countries such as Finland, Sweden, Denmark and New Zealand, where corruption practices are weak, the index is approximately 9. The low corruption-perception index shows that the corruption practices are important in each of these countries. Generally, the subsoil of the sample countries is poor. The average value of the global wealth of the sample countries' subsoil is estimated at $\$ 934.9$, whereas the maximal value is $\$ 24656$. Countries that depend on oil and ore in terms of exporting resources are few. The exportation of oil and ore represents almost $0.97 \%$ of the income of the exportation of countries depending mostly on natural resources. However, on average, the exportation of natural resources represents only $0.24 \%$ of the income stemming from the exportations of all countries in the sample.

Table 2: Descriptive statistics of the variables used in the econometric model

\begin{tabular}{|c|c|c|c|c|c|}
\hline Variable & Obs & Mean & Std, Dev, & Min & Max \\
\hline \multicolumn{6}{|c|}{ Derivation of efficiency scores Model' variables } \\
\hline Prod_Capita & 6581 & 15.24 & 3.31 & 0 & 32.31 \\
\hline Ln_capital & 6581 & 4.24 & 0.82 & 0.69 & 4.63 \\
\hline Ln_Raw_Materials & 6581 & 15.80 & 2.86 & 0 & 22.56 \\
\hline Ln_Firm_Experience & 6581 & 16. & 15.46. & 0 & 2.235 \\
\hline Mangmt_Audited & 6410 & .49 & 0.50 & 0 & 1 \\
\hline Informal_Gift & 6576 & 5989 & 0.28 & 0 & 1 \\
\hline \multicolumn{6}{|c|}{ Determinant of efficiency scores Model' variables } \\
\hline Efficiency (\%) & 6581 & 7.58 & 10.14 & 0 & 100 \\
\hline Corrupt & 6581 & 2.85 & 1.01 & 1.60 & 5.80 \\
\hline Credit & 6581 & 22.64 & 13.01 & 1 & 46 \\
\hline Tax & 6581 & 24.74 & 12.07 & 3 & 46 \\
\hline Buisnss_Doing & 6581 & 151.74 & 32.04 & 46 & 189 \\
\hline SSAS & 6581 & 934.92 & 4125.99 & 0 & 24656 \\
\hline REXP & 6581 & 0.24 & 0.29 & 0 & 0.97 \\
\hline RESPRDN & 6581 & 448.94 & 1104.99 & 0 & 5280 \\
\hline No_landlocked & 6581 & 3290.5 & 0.50 & 0 & 1 \\
\hline Density & 6581 & 67.32 & 88.27 & 3.60 & 480.70 \\
\hline Eco_Open & 6581 & 0.68 & 0.27 & 0.28 & 1.59 \\
\hline FAF & 6581 & 9.36 & 16.49 & 0 & 100 \\
\hline Gov_Contracts & 6581 & 0.245 & 0.43 & 0 & 1 \\
\hline Manufact & 6581 & 0.14 & 0.34 & 0 & 1 \\
\hline Other_Inustry & 6581 & 0.13 & 0.34 & 0 & 1 \\
\hline Service & 6581 & 0.16 & 0.37 & 0 & 1 \\
\hline Retail & 6581 & 0.16 & 0.37 & 0 & 1 \\
\hline Number_Etablism & 5171 & 2.53 & 11.32 & 1 & 500 \\
\hline Foreign_owned & 6444 & 17.08 & 34.86 & 0 & 100 \\
\hline Gov_owned & 6581 & 0.72 & 5.75 & 0 & 99 \\
\hline Manager_experience & 6581 & 13.87 & 10.53 & 0 & 70 \\
\hline Transportation & 6489 & .42 & .49 & 0 & 1 \\
\hline Finance_access & 6403 & .64 & .48 & 0 & 1 \\
\hline Export_Rev_SSA & 6581 & 58.70 & 8.62 & 0 & 100 \\
\hline
\end{tabular}

Source: Built by the authors 
Other important information from table 2 is that the quasi-totality of the firms (5989) pay an illicit amount of money to public agents. The enterprises' standard capital funded by bank credit is also too low. Only $9.36 \%$ of the enterprises' physical capital was acquired through bank credit. Fewer enterprises of the sample are dependent of public tenders. In total, only 1645.25 enterprises applied for the government tenders.

In table 3, we show the number of enterprises per country. The number of enterprises in each country is chosen regarding the country's economic power. Countries where the number of enterprises looks small are those where the economic development is also weak.

Table 3: Proportion of enterprises by country

\begin{tabular}{lccccc}
\hline Country & Manpower & Percentage & Country & Manpower & Percentage \\
\hline Angola & 360 & 5.5 & Ethiopia & 644 & 9.9 \\
Benin & 150 & 2.3 & Gabon & 179 & 2.7 \\
Botswana & 268 & 4.1 & Lesotho & 151 & 2.3 \\
Burkina Faso & 394 & 6.0 & Liberia & 150 & 2.3 \\
Cameroun & 363 & 5.5 & Madagascar & 445 & 6.8 \\
Cap Vert & 156 & 2.4 & Malawi & 150 & 2.3 \\
Central African & 150 & 2.3 & Mali & 360 & 5.5 \\
Republic & 150 & 2.3 & Niger & 150 & 2.3 \\
Chad & 151 & 2.3 & Rwanda & 241 & 3.7 \\
Congo & 526 & 8.0 & Sierra & 150 & 2.3 \\
Côte d'Ivoire & 359 & 5.5 & Teone & 155 & 2.4 \\
DRC & 179 & 2.7 & Zimbabwe & 600 & 9.1 \\
Eritrea & & & & & \\
\hline
\end{tabular}

Source: Built by the authors

Following the presentation of enterprises per country, we will sum up this information at the regional level. On the sub-region level, the East African region is the least represented in terms of the number of enterprises in the sample. Pieces of information in table 4 show that the sample enterprises located in East Africa represent only $16.2 \%$ of the total. This is explained by the fact that fewer countries from that region were considered by the survey. The surveyed countries in this region included Ethiopia, Rwanda and Eritrea. West Africa is the most represented region; its enterprises represent $33.3 \%$ of the sample. The reason is that several countries in this region (Benin, Burkina Faso, Côte d'Ivoire, Mali, Niger, and Togo) were surveyed. Many enterprises from the Southern African region were included in the sample. 
Table 4: Proportion of Enterprises by sub-region of Africa

\begin{tabular}{lcc}
\hline Sub-region & Manpower & Percentages \\
\hline West Africa & 2191 & 33.3 \\
Southern Africa & 1974 & 30.0 \\
Central Africa & 1352 & 20.5 \\
East Africa & 1064 & 16.2 \\
Total & 6581 & 100 \\
\hline
\end{tabular}

Source: Built by the authors

The values of the efficiency scores used in the table 2 have been produced thanks to the first estimation. As the efficiency scores are our interest variable in the second estimation, we propose to study more this variable before presenting the second estimation's results. The first comment that we can make on figure 1 is that the medium level of enterprises' technical efficiency does not depend on the wealth of the countries' subsoil. In other words, wealthysubsoil countries are not necessarily countries with efficient enterprises. For example, countries such as Sierra Leone, Liberia, the Democratic Republic of Congo (DRC) and Gabon have abundant subsoil, but the average technical efficiency of their enterprises is lower than that of countries such as Burkina Faso, Ethiopia, Eritrea and Rwanda, which have poor subsoil. Broadly speaking, we notice that the enterprises' average level of technical efficiency per country is too low. Regarding technical values of efficiency which are supposed to be distributed between 0 and 100, we notice that the highest score values of average technical efficiency do not reach 12 (figure 1). In short, we see from data in figure 1, wealthy countries where the average level of technical scores of efficiency is high (Lesotho and Central African Republic). Likewise, we see poor countries in natural resources whereby the average level of technical scores of efficiency are also high (Zimbabwe, Rwanda and Eritrea).

Among countries rich in subsoil experiencing the lowest average levels of technical efficiency, Sierra Leone, Liberia and DRC are countries that have experienced long periods of war. On the contrary the case in Gabon can be justified otherwise. If Gabon's private enterprises are globally less efficient, this can be justified by issues of governance. Lack of democratic changeover has led a bit to an overstatement of corruption which has damaged the business environment and the quality of infrastructures. Gabon, Togo and Burkina Faso ${ }^{3}$ were run by presidents who stayed in power for a very long time. This may have reduced productive private and public investments in these countries (Akouwerbou, 2016). This implies that private enterprises' productivity can be explained by other factors like quality governance and geographic factors as well (Sachs and Warner, 1997). The enterprises' efficiency is then determined by several factors that will be interesting to identify. In a general way, what is deplorable is that the average level of the enterprises' technical efficiency in each country is very low. The fact that the average per country is highly inferior to $50 \%$ show that a lot of efforts must be done to increase the efficiency of the enterprises settled in the African countries.

\footnotetext{
${ }^{3}$ In Gabon, President Omar Bongo stayed in power from 1967 to 2009 when he died. Likewise, in Togo, President Gnassingbé Eyadema took power in 1967 till his death in 2005. In Burkina Faso, President Blaise Compaoré took power in 1987 till he left office in 2014 following a popular insurection.
} 
Figure 1: Enterprises' average technical efficiency per country

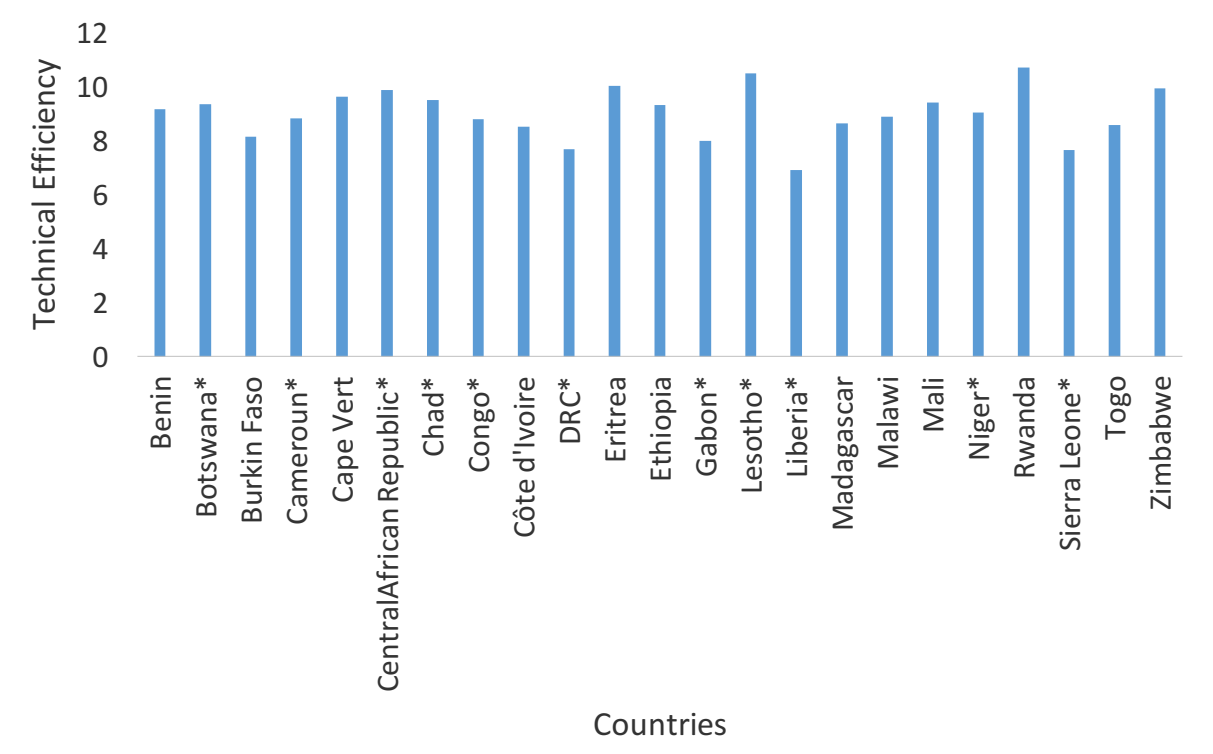

Source: Built by the authors after the first estimation

Legend: * indicates that the country has an abundant subsoil resource.

On the sub-region scale, Southern and Eastern African countries contain the most efficient enterprises. Figure 2 also shows that Central and West Africa's enterprises are the least efficient. We can explain the results at the regional level through diverse factors. The enterprises settled in the Southern and Eastern regions of Africa experience fewer difficulties in the transport sector as well as in the access to the financing (Table A1). The enterprises settled in the Western part of the continent are the most constrained in the access to the bank financing. The data of table A1 of the annex show that $24.8 \%$ of these enterprises do not have access to bank credit while this ratio is but $8.3 \%$ for the enterprises in the Eastern zone of Africa. Concerning the difficulties encountered in the transport sector, the Western African zone is still the most constrained. In this domain, the Eastern zone is viewed as a good example.

By comparing the performances of the different regions showed in figure 2 with the levels of constraints facing by the enterprises in the transport sector and the access to bank credit, we notice that the two constraints are insufficient to justify the enterprises' performance in a region. The Eastern region of Africa is the best example in terms of transport and the access to bank credit (table A1), its enterprises are the most productive ones (figure 2). The enterprises settled in the Southern zone of Africa are also efficient, but these enterprises face some difficulties in terms of access to finances. When we consider the shares of these enterprises owned by foreigners, we realize that this is the zone where foreigners have invested the most in enterprises in Africa (table A1). The enterprises' good performance in this region can then be explained by technologies transfer. If this assumption holds true, we could justify the Western African zone enterprises' performances through the fact that foreigners own less shares of the enterprises settled in the region. But we can notice that West and Central African countries are mostly francophone countries. Yet, for example, in West Africa, entrepreneurship seems to be more developed in Anglophone countries than in Francophone countries. Since gaining their independence, West African Francophone countries have become more involved in politics than in entrepreneurship development, in contrast to the English-speaking colonies in Africa (Dana, 2007). For that reason, not surprisingly that private enterprises settled in these regions are less productive. 


\section{Figure 2: Average technical efficiency of enterprises per sub-region}

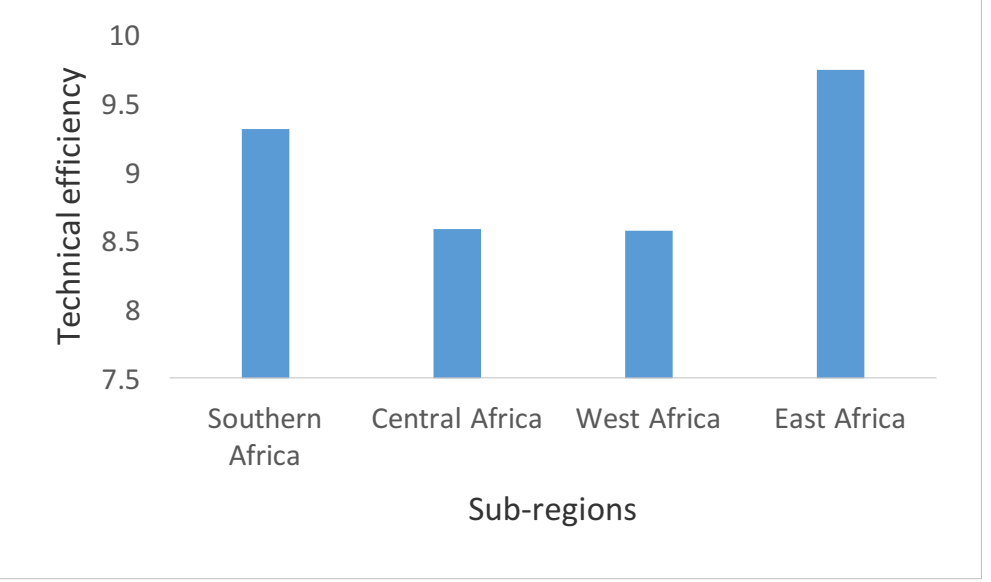

Source: Generated by the authors after the first estimation

\section{Econometric results}

In this section, we present the estimation method and the econometric test of robustness. Then, we interpret and discuss the Tobit model's results.

\section{Method of Estimation}

The estimation of the econometric model first requires conducting a series of tests (e.g., autocorrelation, heteroscedasticity) to detect possible problems that are likely to lead to a biased regressor. The final results are obtained through two stages of estimation. The first stage consists of deriving the enterprises' efficiency scores. In this respect, we use the data envelopment analysis program method [DEAP] to get to that point. The second phase consists of estimating a double truncated Tobit model in which the "Score of Efficiency" variable derived from the previous estimation is the dependent variable. This last estimation enables us to identify the variables influencing the degree of efficiency of the sample enterprises.

The second estimation automatically suffers a problem of endogeneity. As a matter of fact, a country that does not produce energy resources will be in a relative impossibility of exporting this type of resources. Consequently, we suspect the existence of a link between the variable Rexp representing the proportion of fuel and mineral export in total merchandize export and the variable RESPRDN ${ }^{4}$ measuring the per capita production of energy and mining production. For the purpose of controlling this potential problem of endogeneity, we have made used of the instrumental variables method. Thus, we get a model known as Tobit of instrumental variables called IV Tobit. To control for possible problems of heteroscedasticity, we use the robust option to correct the standard errors. In fact, it has been shown that when carry out two distinct estimations as it is in our case, the second estimation is heteroscedastic. The robust option has then been utilized to deal with possible problems of heteroscedasticity.

\section{Interpretation of the results}

We have introduced three representing variables of the countries' level of wealth in natural resources. The concept of wealth in natural resources is comprised of several options. A country can have rich soil; that type of wealth is profitable to a country in developing farming activities. Among the listed African countries, Côte d'Ivoire has that type of natural wealth. A country can also be rich in fauna and flora resources. These resources facilitate tourism

4 The results of this instrumentalisation are presented in appendix (table A2). 
development. In countries such as Kenya, Gabon, the two Congos and the Central African Republic, the subsoil wealth is multifaceted. Countries such as Burkina Faso, Mali, Congo, the Democratic Republic of Congo and the African Central Republic have subsoil rich in ore (e.g., manganese, copper, bauxite, gold). Other countries, such as Niger, Nigeria, and Cameroun, have subsoil rich in energetic resources (e.g., oil, gas, uranium). We take into consideration three cases of natural-resource wealth. We then consider the level of global natural wealth per capita of each country. This indicator was introduced in the literature by the World Bank in 2000. We also retain the share of oil and ore in the exportations. This variable measures the dependence of each country on income from exportation vis-à-vis natural resources. We then consider a variable focusing only on the countries' energetic-resource wealth.

The estimation results of the determinants of enterprises' level of technical efficiency in table 5 enables us to make the following comments: (i) Global natural wealth, regardless of the type of possessed natural resources, negatively influences private enterprises' technical efficiency. However, (ii) as a country's dependence on natural resources in acquiring foreign currencies increases, the enterprises in this country become less technically efficient. Likewise, (iii) enterprises in countries known as big extractors of energy resources and ore are not inefficient. Based on these results, we can draw the following major conclusions. Broadly speaking being settled in a country rich in natural resources is not profitable to the enterprise. When the country where the enterprise is settled depends a lot on exportation incomes stemming from mining and energy products, this negatively affects the enterprise's technical efficiency. However, when an enterprise is settled in a country that extracts tremendous quantities of energy resources, this can be profitable to it. These results show that having considerable natural wealth does not necessarily negatively influence enterprises' productivity. The abundance of natural resources negatively influences enterprises' performance in countries where the governments' budgets are funded with the income from exporting natural resources. This finding implies that normally, when an African country produces huge quantities of a natural resource of which the international price is very high, the enterprises settled in this country are less efficient. This result as aligned with those of Boswort and Collins (2003) and Sachs and Warner (2001) concerning the natural resource curse. These authors have shown that countries that strongly depend on natural resources have a less important labour productivity than countries poor in natural resources.

The results particularly show that settling in a country with many energetic resource stocks is less harmful to enterprises than settling in a country that depends on income from exporting natural resources. When the share of natural resources in the income of exporting increases by a unit, private enterprises' technical efficiency in this country lowers by $15.61 \%$. However, when the country's ability to produce energy natural resources or ore increases by a unit, the private enterprises' technical efficiency in this country increases by $0.48 \%$. In the quasi-totality of African countries, an important share of income comes from exporting natural resources or from extracting energetic resources and ore. This can help to explain why these countries' enterprises efficiencies are very low.

The wealth of natural resources cannot be retained like the only proof of this result. Other empirical obviousness show that the problems of bad governance can also explain the bad performances which the companies of these countries record. The case of the Ivory Coast can be used to illustrate that. This country is not counted among the African countries rich in natural resources. But, it proceeds of the very rich arable lands. The share of the coffee cocoa in the export incomes has exceeded $40 \%$ between 2002 and 2008. The near total of the production of the coffee cocoa is carried out in the rural areas. However, one recorded over the 
same period an increase in the rate of poor passing from $49 \%$ to $62.5 \%$ in the rural areas of this country (FAO, 2009).

From the viewpoint of specialists in transport economics, it is profitable to a country to have direct access to the sea. The sea is also a natural resource in the sense that it is profitable in international trade exchanges. For example, coastal countries' enterprises do not spend much in importing their raw materials. The empirical evidence from our data also supports this hypothesis. Our data show that when we pass from a landlocked country to a coastal country, the enterprises' technical efficiency increases by 7.3\%. In other words, landlocked countries' enterprises are less efficient than coastal ones. Our data seem, then, to support the hypothesis that settling in a country with means of transportation which facilitate international trade can be profitable to a private enterprise. This result is corroborated by the one related to the means of road transport. Our outcomes also confirm that when we go from a country with good quality road infrastructures to another with bad quality road infrastructures, the enterprises' technical efficiency decreases. The intuition of these two outcomes is simple.

The costs of transport play a very important role in an enterprise's competitiveness gains. When the costs of transportation are very high, this leads to an increase of production costs. Likewise, when the costs of transportation are very high, this reduces the enterprise's competitiveness on the international market. This is justified by the fact that the foreign price of products exported by the enterprise will exaggeratedly increase due to the transportation costs. These two constraints showed here slow down the enterprise's activity and even make it less efficient. Certain physical costs can also be identified. When the transportation infrastructures are in bad conditions, this leads to delays in the enterprise's activities. 
Table 5: Results of the estimation of the determinants of enterprises' efficiency

\begin{tabular}{|c|c|c|c|}
\hline $\begin{array}{l}\text { Firm Level } \\
\text { Variables }\end{array}$ & Dy/dx. & $\begin{array}{l}\text { Contry Level } \\
\text { Variables }\end{array}$ & Dy/dx \\
\hline \multirow[t]{2}{*}{ Manufuct } & $11.46^{* *}$ & No_landlocked & $7.309 * * *$ \\
\hline & $(4.861)$ & & $(2.797)$ \\
\hline \multirow[t]{2}{*}{ Other_Industry } & - & Density & $-.186^{* * *}$ \\
\hline & & & $(.0696)$ \\
\hline \multirow[t]{2}{*}{ Services } & $10.44^{* *}$ & Eco_open & - \\
\hline & $(4.883)$ & & \\
\hline \multirow[t]{2}{*}{ Retail } & $-.735^{*}$ & Corrupt(cpi) & $4.931^{* * *}$ \\
\hline & $(.422)$ & & $(1.659)$ \\
\hline \multirow[t]{2}{*}{ FAF } & .0117 & Credit & $-.7^{*}$ \\
\hline & $(.00869)$ & & $(.4)$ \\
\hline \multirow[t]{2}{*}{ Export_Rev_SSA } & -.00433 & Tax & $-.319 * * *$ \\
\hline & $(.0172)$ & & $(.038)$ \\
\hline \multirow[t]{2}{*}{ Number_Etablism } & $-2.32 e-05$ & Business_doing & $-.262^{* * *}$ \\
\hline & $(.000813)$ & & $(.0972)$ \\
\hline \multirow[t]{2}{*}{ Foreign_owned } & -.000441 & SSAS & $-.00202^{* * *}$ \\
\hline & $(.00418)$ & & $(.000679)$ \\
\hline \multirow[t]{2}{*}{ Gov_owned } & & Rexp & $-4.645^{*}$ \\
\hline & & & $(2.381)$ \\
\hline \multirow[t]{2}{*}{ Firm_experience } & -.00982 & RESPRDN & $.00483^{* * *}$ \\
\hline & $(.0104)$ & & $(.00177)$ \\
\hline \multirow[t]{2}{*}{ Manaer_experience } & .00837 & Gov_contrats & -.306 \\
\hline & $(.0152)$ & & $(.316)$ \\
\hline \multirow[t]{2}{*}{ Finace_access } & -.399 & & \\
\hline & $(.322)$ & & \\
\hline \multirow[t]{2}{*}{ Transportation } & $-.618^{* *}$ & Constant & $70.56^{*}$ \\
\hline & $(.292)$ & & $(39.54)$ \\
\hline \multirow[t]{2}{*}{ Sigma } & 6.607 & $\begin{array}{l}\text { Log } \\
\text { pseudolikehood }\end{array}$ & -6101.7522 \\
\hline & $(8.150)$ & & \\
\hline \multirow[t]{2}{*}{$\ln s$} & $2.304^{* * *}$ & & \\
\hline & $(.0213)$ & & \\
\hline
\end{tabular}

\section{Source: Built by the authors from the results of estimation}

Legend: Standard robust errors in brackets

$* * *, * *$, and * imply, respectively, significance at $1 \% ; 5 \%$ and $10 \%$.

Dy/dx are the marginal effects

\section{DISCUSSION}

As predicted by the specialists of transport economics, we find that conducting business in a coastal country positively influences private enterprises' productivity. We find consequently a result different from that of the African Development Bank (2007). The statistics published by this institution emphasized that coastal countries did not experience more economic growth than landlocked countries. Torvick (2001) and Sachs and Warner (1995) estimated that manufacturing enterprises are penalized in countries wealthy in natural resources. Our data do not support this hypothesis. Our data show that being a manufacturing industry in our sample is an advantage. 
Economists have acknowledged that it is important for an enterprise to have access to credit. Gatti and Love (2008) showed that when an enterprise does not have access to a bank loan, inefficiencies arise. African country leaders have implemented many strategies to facilitate private enterprises' access to bank credit. However, unfortunately the problems of moral hazard and asymmetric information (Stiglitz and Weiss, 1981) have not helped African banks grant much credit to private enterprises. The Table 5 data show that the difficulty for an enterprise to get bank credit negatively affects its technical efficiency scores. This classical result has been highlighted by authors such as Levine (2005) and Beck and Laeven (2004).

As Fisman and Love (2004) did, we also find that as the amount of taxes private enterprises pay increases, they become less technically efficient. Paying more taxes negatively influences the private enterprises' productivity because the amounts paid in taxes represent a decrease in the private enterprises' financial resources (Johansson et al., 2009; Levine, 2001). In the same way, we find that enterprises settled in countries where it is difficult to set up and manage an enterprise are less efficient than those settled in a stabilized business environment. This result explains why the World Bank and the International monetary fund (IMF) have introduced the project of Doing Business to help African countries stabilize their economic environments.

Our results show that enterprises in manufacturing and services are more efficient. The degree of the country's openness have not any influence on the score of the enterprises' technical efficiency. However, being settled in a more populated country is not an advantage for the sample enterprises. As the density of an African country increases, the population's access to education and health care decreases, and the labour is less qualified (African Bank, 2007). The low labour productivity can then explain why the enterprises in these countries are less efficient.

Our data seem to support the assumption of efficient grease. This assumption expressed by Kaufmann and Wei (1999) and Leff (1964) stipulates that the practices of corruption improve the private enterprises' productivity. According to the followers of this theory, corruption enables the enterprises to avoid the administrative slowness and the public agents' exactions. In the developing countries, these constraints largely slow the private enterprises' activities. By avoiding them through the payment of bribes, the enterprises increase their productivity. Our econometric results show that more efficient are the enterprises settled in countries where the practices of corruption are too much well-spread.

\section{CONCLUSION}

In this article, we try to show the existence of the natural resource curse based on enterprise data. In a 1995 published study, Sachs and Warner showed that countries wealthy in natural resources record lower economic growth rates than countries with fewer such resources. This phenomenon, called the natural resource curse, has been the topic of several macroeconomic studies that have reached the same conclusion. The current article fills a gap in this literature. To contribute to this literature, we use private enterprises' data collected by the World Bank in several African countries.

The purpose of our study is to show that enterprises settled in countries poor in natural resources are more efficient than those settled in countries wealthy in natural resources. We implement a two-stage method to get to that point. First, we use the DEA method to derive the enterprises' technical efficiency scores. Then, we use the IV Tobit model to identify the determinants of these efficiency scores. 
The data analysis enables us to conclude the following: $\left(r_{i}\right)$ The abundance of natural resources does not cause the resources curse. Our results show that enterprises are more efficient in countries where an important quantity of energy resources is extracted. $\left(r_{i i}\right)$ The resource curse originates from a country's economic dependence vis-à-vis the income from exporting natural resources. In other words, as the importance the share of the natural resources in the income from exportation increases the efficiency of the enterprises decreases. We also find that $\left(r_{i i i}\right)$ enterprises settled in the countries extracting and exporting many the energetic resources are more inefficient. This result is only the consequence of the result in (rii) in the sense that countries that export energetic natural resources are mostly dependent on the income from exporting these resources.

In addition to the variables representing the country's wealth in natural resources, we have identified other factors influencing the private enterprises' productivity. The enterprises settled in the landlocked African countries are technically far to the production frontier. But, the enterprises doing business in countries where the bank credit is unattainable as well as those paying a lot of taxes are inefficient. Contrary to the anticipations of Sachs and Warner (1995), Matsuyama (1992) and Gylfason and al. (1999), our data do not support the hypothesis that the manufacturing enterprises are penalized comparing to other types of industries. The enterprises settled in the coastal countries profit with their proximity to the sea to reduce their technical inefficiency.

With enterprises' data, we have shown the existence of the natural resources curse. Another main innovation of our approach resides in using the joint data (micro and macro). Future researches can improve our methods by using microeconomic data at firm level which measure the macroeconomic variables used in our study. It would be important to adopt our approach by purely using microeconomic data, so as to deepen certain important aspects of this thematic. For example, microeconomic data would enable to take into consideration the fact that two enterprises settled in the same country do not consider in the same way the constraints linked to corruption, taxes and the access to public procurements, etc. Likewise, enterprises doing business in two different branches of business may not see the same way the constraints linked to the labor quality, the public agents' extortion, the quality of the means of transportation, etc.

\section{ACKNOWLEDGMENTS}

The author is grateful to Micheline Goedhuys, UNU-MERIT, The Netherlands and all the participents of the second Africalics annuel conference for the comments on this article's previous versions. He is also thankful to Romain Kiragoulou and Kini Janvier for their contribution in improving the English.

\section{FUNDING}

The author(s) disclosed receipt of the following financial support for the research and/or authorship of this article: The author acknowledges financial support by Africalics.

\section{References}

Acemoglu, D., Robinson, J. A., and Verdier, T. (2004). Kleptocracy and Divide-and-rule: A Theory of Personal Rule, Journal of the European Economic Association, 2, 162-92.

African Development Bank, (2007). Africa's natural Resources: The paradox of plenty. Chapiter 4.

Aghion, P., Caroli, E., Garcma-Penalosa, C., (1999). Inequality and economic growth: The perspective of the new growth theories. Journal of Economic Literature 37, 1615-1660.

Ahrend, R., (2006). How to sustain growth in resource based economy? The main concept and their application to the russian case. OECD Economics working paper $n 478$ 
Akazili, J., Adjuik, M., Jehu-Appiah, C., and Zere, E. (2008). Using data envelopment analysis to measure the extent of technical efficiency of public health centres in Ghana. BMC International Health and Human Rights, 8:11.

Akouwerabou, D.B. (2016) What determines enterprises' technical efficiency? An empirical investigation of informal enterprises in Burkina Faso, Int. J. Entrepreneurship and Small Business, Vol. 28, Nos. 2/3, pp.359-379.

Atkinson, G. and Hamilton, K. (2003). Savings, growth and the resource curse hypothesis, World Development, 31(11), 1793-1807.

Auty, RM., and Mikesell, R.F. (1998). Sustainable Development in Mineral Economies.

Barro RJ., Sala-i-Martin (1995). Economic Growth. New York McGraw-Hill.

Barro, R.J., (1997). The Determinants of Economic Growth. MIT Press, Cambridge, MA.

Barro, RJ., (1991). Economic growth in a cross section of countries. Quarterly Journal of Economics, vol. 106, pp. 407-443.

Beck, T., and Laeven, L., (2004). Institutions and Growth in Transition Economies, World Bank Working Paper.

Birdsall, N., Pinckney, T., Sabot, R., (2001). Natural Resources, Human Capital, and Growth. In Resource Abundance and Economic Development, ed. Richard M. Auty. Oxford: Oxford University Press.

Bosworth, B. and Collins, SM., (2003). The Empirics of Growth: An Update. Brookings papers on economic activity. 2 pp. 113-206 | 10.1353/eca.2004.0002.

Bravo-Ortega, C., Gregorio, J., (2007). The relative richness of the poor? Natural resources, human capital and economic growth. In: Lederman, D., Maloney, W. (Eds.), Resources, Neither Curse nor Destiny. Stanford University Press, Washington, DC, Chapter 4, pp. 7199.

Charnes A, Cooper W, Lewin AY, Seiford LW (1994). Data Envelopment Analysis: Theory. Methodology and Applications Kluwer Academic Publishers.

Coelli TJ. (1996). A guide to DEAP version 2.1: A Data Envelopment Analysis Programme. In CEPA working paper 96/8, department of econometrics. University of New England.

Dana, LP. (2007) Promoting SMEs in Africa: Some Insights from an Experiment in Ghana and Togo. Journal of African Business, 8(2), 151-174.

De Long, J.B., and Williamson, J.G., (1994). Natural Resources and Convergence in the Nineteenth and Twentieth Centuries, Unpublished paper, Harvard University.

Farell M.. (1957). The measurement of productive efficiency, Journal of the Royal statistical Society, Series A 120: 195-211.

Farhadi, M., Islam, MDR. And Moslehi, S., (2013). Growth failure of resource-rich Economies: Roles of Goverment Activities.

Fisman, R. and I. Love (2004). Financial Dependence and Growth: Comment, World Bank Working Paper.

Gatti, B.; and Love, I., (2008) Does access to credit improve productivity? Evidence from Bulgarian firms. Economics of transition, 16(3), 445-465.

Gylfason, T. (2001a). Natural resources and economic growth; what is the connection', CESifo Working Paper No. 50.

Gylfason, T. (2001b). Natural resources, education and economic development, European Economic Review, 45(4), 847-859.

Gylfason, T., Herbertsson, TT. ; Zoega, G. (1999). A mixed blessing. Natural Resources and Economic Growth. Macroéconomic Dynamics, vol. 3, pp. 204-225. Printed in the United States of America.

Hartford, T., Klein, M. (2005). Aid and the resource curse, The World Bank Group, Private Sector Development Presidency Note No. 291 (Washington, DC: World Bank).

Hirschman (1958). The Strategy of Economic Development, New Haven, Yale University Press.

Isham, J., Woodcock, M., Pritchett, L.,Busby, G. (2005). 'The varieties of resource experience: natural resource export structures and the political economy of economic growth', World Bank Economic Review, 19(2), 141-174. 
Johansson, A. ; Heady, C. ; Arnold, J. ; Brys, B., and Vartia, L., (2009). Taxes and Firm performance: evidence from the OECD. Tax Reform in a Globalising world. International and country perspectives, edited by Claus, I., Gemmell, N.; Harding, M. and White, D. Published by Edward Elgar.

Kaufmann D, Wei SJ. Does grease money speed up the wheels of commerce? Vol 64 of International Monetary Fund, NBER working paper series.

Kaufmann, D.; Kraay, A.; and Mastruzzi, M. (2007) Governance Matters VI: Governance Indicators for 1996-2006. World Bank Policy Research Working Paper No. 4280.

Krugman, P., (1987). The narrow moving band, the Dutch disease, and the competitive consequences of Mrs. Thatcher: notes on trade in the presence of dynamicscale economies. Journal of Development Economics, vol. 27, pp. 41-55. North-Holland.

Leff N. Economic development through bureaucratic corruption. American Behavioral Scientist. 1964;8(3):8-14.

Levine, R., (2001). Stock Markets, Growth, and Tax Policy, Journal of Finance, 46, 1445-1465.

Levine, R., (2005). Finance and Growth: Theory and Evidence, in: Philippe Aghion \& Steven Durlauf (ed.), Handbook of Economic Growth, (ed.), Handbook of Economic Growth, edition 1, volume 1, chapter 12, pages 865934 Elsevier.

Liu Y. and Myers R., (2009). Model selection in stochastic frontier analysis with an application to maize production in Kenya? J. of Product. Anal. 31(1):33-46.

Mankiw, NG., Romer, D., and Weil, DN. (1992). A contribution to the empirics of economic growth. Quarterly Journal of Economics, 107, pp.407-437.

Matsuyama, K. (1992). Agricultural Productivity, Comparative Advantage, and Economic Growth. Journal of Economic Theory, 58, pp. 317-334.

Mauro, P. (1995), Corruption and Growth, Quarterly Journal of Economics, 110(3), 681-712.

Mehlum, H. Moene, K. and Torvik, R. (2006a), Cursed by resources or institutions? The World Economy, 29(8), 1117-31.

Mehlum,H.,and Moene, K. and Torvik, R. (2006b), Institutions and the Resource Curse, The Economic Journal,116, $1-20$.

Papyrakis, E., \& Gerlagh, R., (2007). Resource abundance and economic growth in the United States, European Economic Review, Elsevier, 51(4), pages 1011-1039.

Prebisch, R. (1950). The economic development of Latin America and its principal problems. Lake Success, NY: United Nations.

Qureshi, M S., (2008). Africa's Oil Abundance and External Competitiveness: Do Institutions Matter? International Monetary Fund.

Rodriguez, F., \& Sachs, JD. (1999). Why do resource abundant economies grow more slowly? A new explanation and an application to Venezuela. Journal of Economic Growth, 4, 277-303.

Sachs JD., Warner A. (1997). Sources of slow growth in African economies. Journal of African economies 6(3), 335376.

Sachs, DJ., Warner, AM. (1999). The big push, natural resource booms and growth, Journal of Development Economics, 59(1), 43-76.

Sachs, J., Warner, A. (2001). The curse of natural resources, European Economic Review, 45(4), 827-38.

Sachs, JD., Warner, AM., (1995). Natural Resource abundance and Economic Growth. NBER working paper Series, Paper 5398.

Sala-i-Martin, X., Subramanian, A. (2003). Addressing the natural resource curse: an illustration from Nigeria, NBER Working Paper No. 9804.

Sim, P (2013). Natural resource and Economic Growth: the conditional curse. The International journal of Economic Policy Studies, vol. 8(6), 113-142.

Stevens, P., Lahn, G. and Kooroshy, J., (2015). The Reources curse Revisited. Chatham House, the Royal Institute of International Affairs, pp 5-18 and 28-45.

Stiglitz, JE., Weiss, A., (1981). Credit Rationing in Markets with Imperfect Information. The American Economic Review, 71(3), 393-410 
Torres, N.; Alfonso, O., Soares, I. (2013). A survey of Literature on the Resource curse: Critical Analysis of the Main Explanations, Empirical Tests and Resource Proxies. Centre de Economia eFiaceas da UP. Working paper. www.fep.up.pt.

Torvik, R. (2002). Natural Resources, Rent Seeking and Welfare, Journal of Development Economics, 67, 455-70.

Torvik, R. (2001). Learning by doing and the Dutch Disease. European Economic Review, vol. 45, pp. $285-306$.

Torvik, R. (2009). Why do some resource-abundant countries succeed while others do not? Oxford Review of Economics Policy, vol 25 (2), pp. 241-256.

Van der Ploeg, F. (2011). Natural resources: Curse or blessing? Journal of Economic Literature 49(2): 366-420.

Wright, G., and J. Czelusta. (2007). Resource-based growth past and present. Natural Resources: Neither Curse Nor Destiny, 185. Stanford University Press, 369 pages. 


\section{ANNEX}

Tableau A1 : Some statistics concerning other variables

\begin{tabular}{lcccc}
\hline Sub-Region & \multicolumn{2}{c}{$\begin{array}{c}\text { How much are the } \\
\text { Obtacles (\%) }\end{array}$} & $\begin{array}{c}\text { \% owned by Foreign private individuals or } \\
\text { Entreprises or Organisation }\end{array}$ \\
\cline { 2 - 3 } & Transport & Finance & \\
\hline Central Africa & 10.1 & 10.2 & 30.4 \\
Austral Africa & 8.2 & 20.3 & 33.7 \\
West Africa & 18.1 & 24.8 & 15.1 \\
East Africa & 5.1 & 8.3 & 20.8 \\
\hline
\end{tabular}

Source: Set up by the authors from the data

Figure B1: Polynomial smooth of Efficiency Scores obtained by parametric method

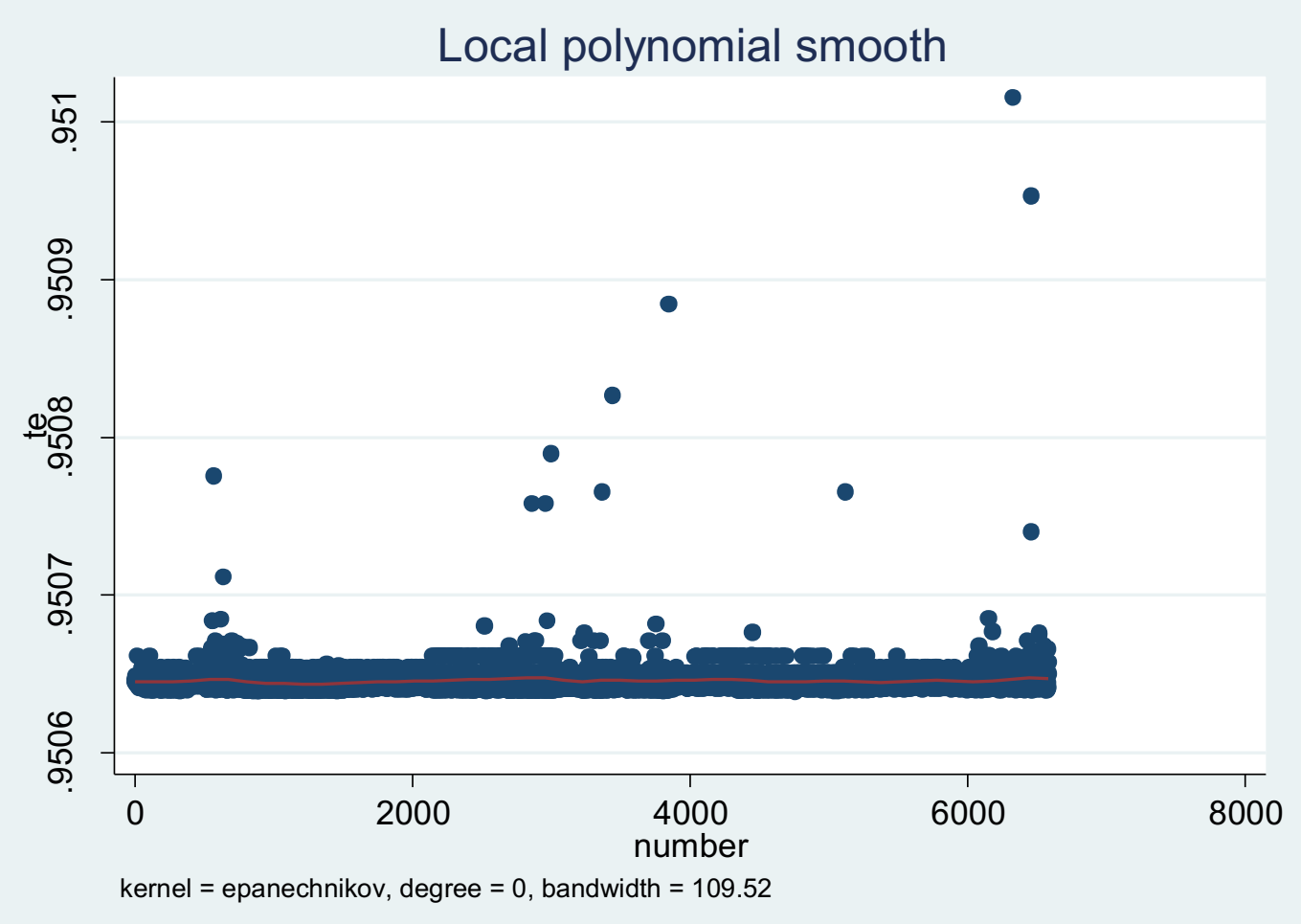

Source : Built by the authors 
Figure B2: Polynomial smooth of Efficiency Scores obtained by non-parametric method

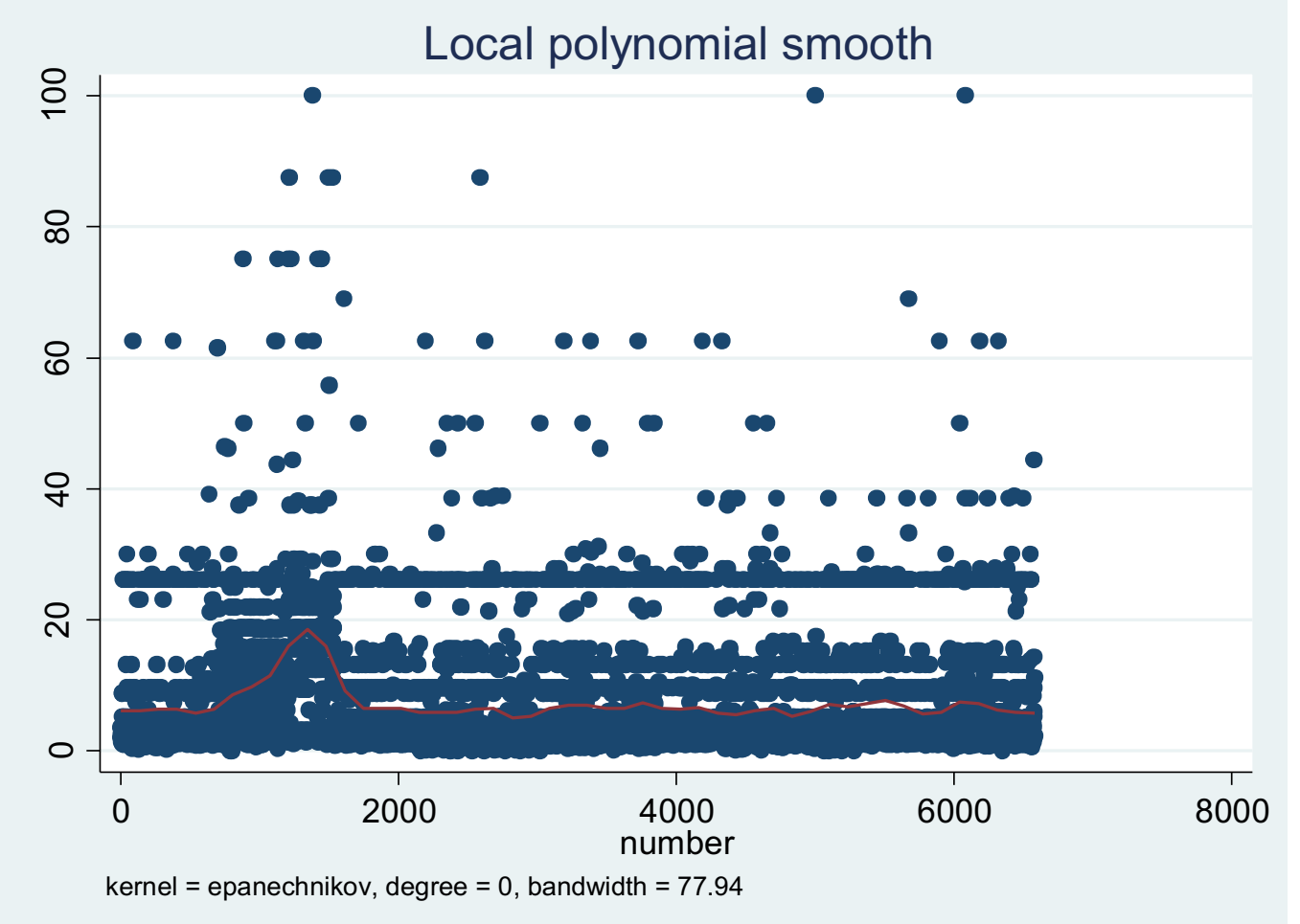

Source : Built by the authors 
Table A2: The IV estimation of the determinants of REXP

\begin{tabular}{|c|c|c|c|}
\hline $\begin{array}{l}\text { Firm Level } \\
\text { Variables } \\
\end{array}$ & Dy/dx. & $\begin{array}{l}\text { Contry Level } \\
\text { Variables }\end{array}$ & $\mathrm{Dy} / \mathrm{dx}$ \\
\hline \multirow[t]{2}{*}{ Manufuct } & 0.468 & No_landlocked & 0.250 \\
\hline & $(0.438)$ & & $(0.181)$ \\
\hline \multirow[t]{2}{*}{ Other_Industry } & $-0.00140^{* *}$ & Density & $-0.0370^{* * *}$ \\
\hline & $(0.000654)$ & & $(0.00421)$ \\
\hline \multirow[t]{2}{*}{ Services } & 0.467 & Eco_open & $-1.338^{* * *}$ \\
\hline & $(0.439)$ & & $(0.0292)$ \\
\hline \multirow[t]{2}{*}{ Retail } & $-0.00210^{* * *}$ & Corrupt(cpi) & -0.000269 \\
\hline & $(0.000661)$ & & $(0.00278)$ \\
\hline \multirow[t]{2}{*}{ FAF } & $-1.75 e-05$ & Credit & $-0.133^{* * *}$ \\
\hline & $(1.11 \mathrm{e}-05)$ & & $(0.0427)$ \\
\hline \multirow[t]{2}{*}{ Export_Rev_SSA } & $-3.05 e-05$ & Tax & $-0.0641^{* *}$ \\
\hline & $(2.18 \mathrm{e}-05)$ & & $(0.0317)$ \\
\hline \multirow[t]{2}{*}{ Number_Etablism } & $0.000115^{* * *}$ & Business_doing & $-0.0582^{* * *}$ \\
\hline & $(1.79 \mathrm{e}-05)$ & & $(0.00649)$ \\
\hline \multirow[t]{3}{*}{ Foreign_owned } & - & SSAS & - \\
\hline & $0.000122^{* * *}$ & & $0.000464^{* * *}$ \\
\hline & $(1.99 \mathrm{e}-05)$ & & $(4.14 \mathrm{e}-05)$ \\
\hline \multirow[t]{2}{*}{ Gov_owned } & - & RESPRDN & $0.00147^{* * *}$ \\
\hline & $\begin{array}{l}0.000170 * * * \\
(4.25 \mathrm{e}-05)\end{array}$ & & $(3.09 e-05)$ \\
\hline \multirow[t]{2}{*}{ Firm_experience } & $2.80 \mathrm{e}-05$ & Gov_contrats & -0.000291 \\
\hline & $(1.86 \mathrm{e}-05)$ & & $(0.000485)$ \\
\hline \multirow[t]{2}{*}{ Manaer_experience } & $-6.17 e-05^{* *}$ & & \\
\hline & $(2.45 \mathrm{e}-05)$ & & \\
\hline \multirow[t]{2}{*}{ Finace_access } & $0.00505^{* * *}$ & Constant & $16.81^{* * *}$ \\
\hline & $(0.000914)$ & & $(3.033)$ \\
\hline \multirow[t]{2}{*}{ Transportation } & $0.00233^{* * *}$ & & \\
\hline & $(0.000582)$ & & \\
\hline \multirow[t]{2}{*}{ Sigma } & & $\begin{array}{l}\text { Log } \\
\text { pseudolikehood }\end{array}$ & -6101.7522 \\
\hline & $(8.150)$ & & \\
\hline \multirow[t]{2}{*}{$\ln s$} & $2.304^{* * *}$ & & \\
\hline & $(0.0213)$ & & \\
\hline
\end{tabular}

Source: Built by the authors from the results of IV estimation 